\title{
Air pollution: how many cigarettes does each Pole 'smoke' every year and how does it influence health, with special respect to lung cancer?
}

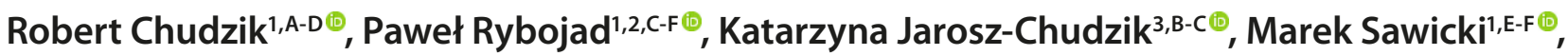 \\ Beata Rybojad ${ }^{4,5, \mathrm{C}, \mathrm{E}-\mathrm{F} \oplus}{ }^{\oplus}$, Lech Panasiuk ${ }^{6, \mathrm{E}-\mathrm{F} \oplus}$ \\ ${ }^{1}$ Chair and Department of Thoracic Surgery, Medical University, Lublin, Poland \\ ${ }^{2}$ Department of Thoracic Surgery, Holy Cross Cancer Centre, Kielce, Poland \\ ${ }^{3}$ Independent Public Clinical Hospital No. 4, Lublin, Poland \\ ${ }^{4}$ Department of Emergency Medicine, Medical University, Lublin, Poland \\ ${ }^{5}$ Department of Anaesthesiology and Intensive Care, Children's University Hospital, Lublin, Poland \\ ${ }^{6}$ Institute of Rural Health, Lublin, Poland \\ A - Research concept and design, B - Collection and/or assembly of data, C - Data analysis and interpretation, \\ $D$ - Writing the article, E-Critical revision of the article, F - Final approval of article
}

Chudzik R, Rybojad P, Jarosz-Chudzik K, Sawicki M, Rybojad B, Panasiuk L. Air pollution: how many cigarettes does each Pole 'smoke' doi: 10.26444/aaem/109974

\begin{abstract}
Introduction. Air pollution is one of the most important issues of our times. Air quality assessment is based on the measurement of the concentration of substances formed during the combustion process and micro-particles suspended in the air in the form of an aerosol. Microscopic atmospheric particulate matters (PM) 2.5 and 10 are mixtures of organic and inorganic pollutants smaller than 2.5 and $10 \mu \mathrm{m}$, respectively. They are the main cause of negative phenomena in the earth's atmosphere of Earth and human health, especially on the respiratory and cardiovascular systems. Particulates have the ability to cause permanent mutations of tissue, leading to neoplasms and even premature deaths. Nitrogen dioxide (NO2) is one of the main pollutants which arises mainly during the burning of fossil fuels. Based on numerous scientific researches, it has been proved that long-term exposure to NO2 could increase morbidity of cancer due to inflammatory processes increasing abnormal mutations.

Materials and method. Data available in the Polish National Cancer Registry, Chief Inspectorate for Environmental Protection and Map of Health Needs in the Field of Oncology for Poland, WHO Air Quality Guidelines 2005 were analyzed. Air pollution was also evaluated: PM2.5, PM10, NO2, and compared with lung cancer morbidity.

Results and conclusions. Based on the available data and literature, it can be concluded that in 2009-2017, on average, each Pole smoked ten cigarettes a day $+/-2$. Therefore, it can be estimated that after 60 years everyone had 30 package-years of smoking, leading to a high risk of lung cancer and other smoking related diseases. Additionally air quality in Poland is not satisfactory, exceeding the standards presented in the WHO Guidelines 2005. It can be assumed that this may translate into an additional, independent continuous increase in morbidity and mortality dependent on smoking.
\end{abstract}

\section{Key words}

lung cancer, PM2.5, air pollution, nitrogen dioxide, PM10

\section{INTRODUCTION}

Air pollution can be emitted to the atmosphere or formed in the same atmosphere. Primary air pollutants are those which are emitted from sources such as chimneys or exhaust systems, or by suspension of contaminated particulate matters in the wind. Secondary air pollutions are those which arise in the same atmosphere and result from the chemical reaction of the original pollution, involving natural components of the atmosphere, particularly oxygen and water. The best known example is ozone, but a significant portion of atmospheric nitrogen dioxide (NO2) is also a secondary product of atmospheric chemistry.

Address for correspondence: Robert Chudzik, Chair and Department of Thoracic Surgery, Medical University of Lublin, Poland

E-mail: robertch7@gmail.com

Received: 27.03.2019; accepted: 10.06.2019; first published: 08.07.2019
Nitrogen oxides are one of the important elements of pollution that arise in the combustion process. Coal is the most dangerous fuel in this respect, because oil and gas contain much lower levels of nitrogen. Most importantly, $80 \%$ of the electricity produced in Poland comes from coal [1]. However, there is an additional process in which atmospheric nitrogen and oxygen are combined in high-temperature combustion. This happens in all high-temperature combustion processes, which explains why traffic pollution is one of the main sources of these gases, despite a lower nitrogen content. Most of the oxides of nitrogen produced in this way are transmitted as nitric oxide. Usually only $5 \%$ of the total, is transmitted as a basic nitrogen dioxide, while the greater part of the atmospheric $\mathrm{NO} 2$ is a secondary product of chemical processes in the atmosphere.

The main sources of NO2 in the air of European cities are emissions from road traffic, especially from vehicles with 
diesel engines [2], and limit values are very often exceeded in European cities. The spatial distribution of emissions is very uneven - it reaches the highest level in large urban areas and main industrial districts.

Exposure to air pollution has increased the risk of developing cardiovascular diseases and malignant neoplasms by $30 \%$ between 1990 - 2013 [3]. In Europe, PM2.5 is responsible for lowering the average life span by 8.6 months [4]. Researchers in the USA have proved that long-time exposure to PM2.5 not only increases cardiopulmonary problems, but also morbidity and mortality of lung cancer [5].

In 2012, lung cancer was the most deadly cancer among men and women. It was also the third most common cancer, after cancer of the breast and large intestine [6]. According to the latest available data (2016), the epidemiologic situation of lung cancer in Poland is very similar to the global trend [7]. This is one of the most aggressive cancers with not very effective screening possibilities, with a 5-year average survival rate (irrespective of stage) of $10-15 \%$. Worldwide, lung cancer is the main cause of death among cancer patients $[6,7]$, which makes it an important subject of research, both in the treatment and reduction of morbidity and mortality. In the literature, there are increasingly more reports providing compelling evidence about the factors that contribute to the development of lung cancer. One of the main causes still remains tobacco smoking (also passive smoking). In addition, exposure to asbestos, radon, polycyclic aromatic hydrocarbons and crystalline silica contribute to lung cancer incidences. In the discussion about the threat of lung cancer, air pollution is rarely mentioned as an important factor for carcinogenesis. Numerous of studies conducted since 1828 have confirmed that chronic inflammation could lead to carcinogenesis [10]. Current studies on mice [11], rats [12] and in vivo on lung cells [13], confirm that PM2.5, $\mathrm{PM} 10$, and combustion gases, including NO2, can lead to inflammation and irreversible mutations resulting in the formation of cancer [14, 15, 16, 17, 18]. PMs and NO2 [19], as well as other air pollutants, are important, especially when bearing in mind that $10-25 \%$ of all lung cancers occur in people who have never smoked cigarettes [20]. Recently, there have been many reports which have closely linked air pollution with lung cancer. Even special applications and computer programmes have been created, converting the level of pollution into the number of cigarettes smoked, which facilitates the analysis of morbidity and mortality connected with lung cancer.

The presented study shows the air quality in Poland in the relation with the increasing incidence of lung cancer. This is an important topic, not only because of the increasing incidence of lung cancer, but also the condition of air in Poland which annually exceeds the standards proposed by the WHO.

There have been many studies showing the state of air quality in Poland, and mMost of them have compared the degree of the air pollution, and incidences of different neoplasms. The method of transcription the air pollution to the amount of passively smoked cigarettes presented in the current study, was elaborated in 2016 by Saskia C. Vander Zee, Paul H. Fischer and Gerard Hoek. This new tool seems to be highly efficient and enables much quicker analysis, not only for clinicians but also for society and the authorities responsible for health and environmental policy.

\section{MATERIALS AND METHOD}

Research for this study began with a review of literature about air pollution and its influence on carcinogenesis, particularly on lung cancer. Subsequently, a review was conducted of the WHO Air Quality Guidelines 2005, and comparing them with the UE Air Quality Standards, Environmental Protection Act of 27 April 2001, and Ordinance of the Minister of the Environment of 24 August 2012 on the levels of certain substances in the air. The levels of air pollutants (PM 2.5, PM 10, NO2) for Poland in 2009-2017, were obtained from the database of the Chief Inspectorate of Environmental Protection. Values for PM2.5, PM 10 and NO2 are average annual figures calculated on the basis of measurements taken every hour from all measuring points in Poland, ac well as the number of exceeded standards for PM 10: average number of exceeded standards - over 50ug / m3 every $24 \mathrm{~h}$ for all measuring stations.

The standard incidence and cumulative risk of morbidity for lung cancer (ICD10 - C34) - were obtained from the National Cancer Registry (2009-2016). The number of recorded cases of lung cancer were also compared with predictions made by the Ministry of Health in the prepared Health Maps of needs for oncology in 2029 (ICD10 - C33 + C34). Based on the available data and using the method prepared by Saskia C. Vander Zee, Paul H. Fischer, Gerard Hoek, Air pollution in perspective: Health risks of air pollution expressed in equivalent numbers of passively smoked cigarettes [21], how many cigarettes each Polish resident passively smokes in a year were calculated.

\section{RESULTS}

Numerous studies indicate a plurality of factors which increase the risk of lung cancer - many of which we breathe in every day. As a result, the WHO has published guidelines for individual substances in the air, including: PM 2.5, PM 10 and NO2. [22] Similar guidelines, however more liberal, were published by the European Commission [23], which are the same as the norm in Poland - the Environmental Protection Act 2001 [24].

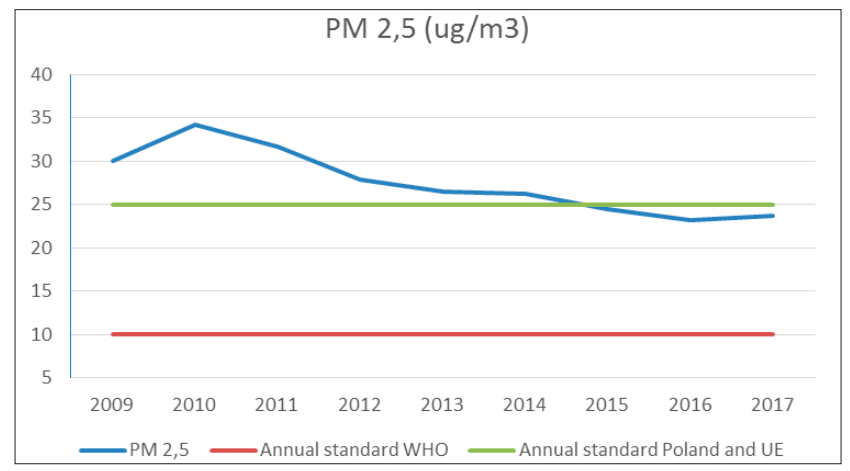

Figure 1. Average annual concentration of PM2.5 [22]

A slight downward trend has been observed of PM2.5 concentration in Poland, but the results still exceed the recommended values by almost 2.5-3 times. It is worth noting that the existing standards are not only recommended by the WHO, but also by Polish and European legislation, which are far more liberal. 


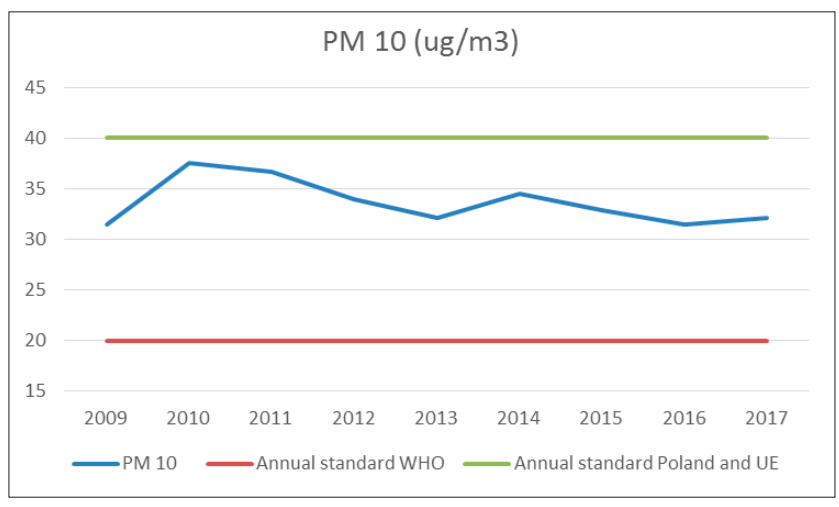

Figure 2. Average annual concentration of PM 10 [22]

Table 1. Average number of exceeded measurements PM10 [22]

\begin{tabular}{|c|c|c|c|c|c|c|c|c|c|}
\hline & 2009 & 2010 & 2011 & 2012 & 2013 & 2014 & 2015 & 2016 & 2017 \\
\hline $\begin{array}{l}\text { Average number } \\
\text { of exceeded } \\
\text { measurements } \\
\text { PM10 }\end{array}$ & 53 & 64 & 63 & 57 & 57 & 59 & 54 & 45 & 47 \\
\hline $\begin{array}{l}\text { Permitted } \\
\text { exceedances each } \\
\text { year PM10: EU } \\
\text { and PL }\end{array}$ & & & & & 35 & & & & \\
\hline
\end{tabular}

As can be seen, the PM10 concentration has a slight increasing tendency in Poland. As in the case of PM2.5, there is a divergence of guidelines between the WHO and EU / Polish legislation. The first are not respected while the EU and National norms are; in the cirrent study - the average values were analyzed. The excesses permitted in national law are not respected, and it is worth noting that the WHO does not allow any excess beyond the stipulated standards.

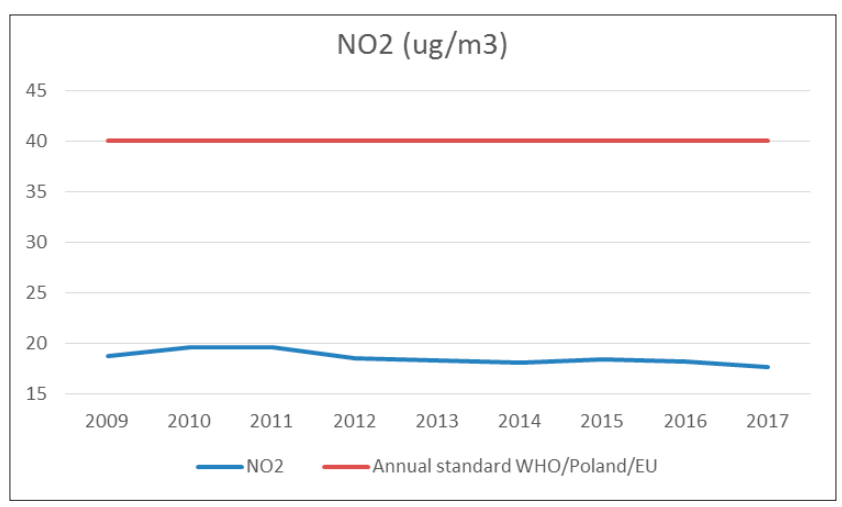

Figure 3. Average annual concentration of $\mathrm{NO} 2$ [22]

WHO, EU and Polish guidelines for NO2 concentration are the same. Measurements in recent years have a similar level and meet the recommendations.

The incidence of lung cancer in Poland is steadily increasing. According to the Health Maps of needs for oncology, prepared by the Polish Ministry of Health, this tendency will continue. In the available literature, there can also be found other data on the predicted incidence of lung cancer in Poland, Predictions of cancer mortality in Poland in 2020 and Determinants of Propensity for Cigarette Smoking. Results of Structural Equation Modelling [26, 27]. However, due to the fact that the Ministry of Health is the decisionmaker in shaping health policy, in the current study the

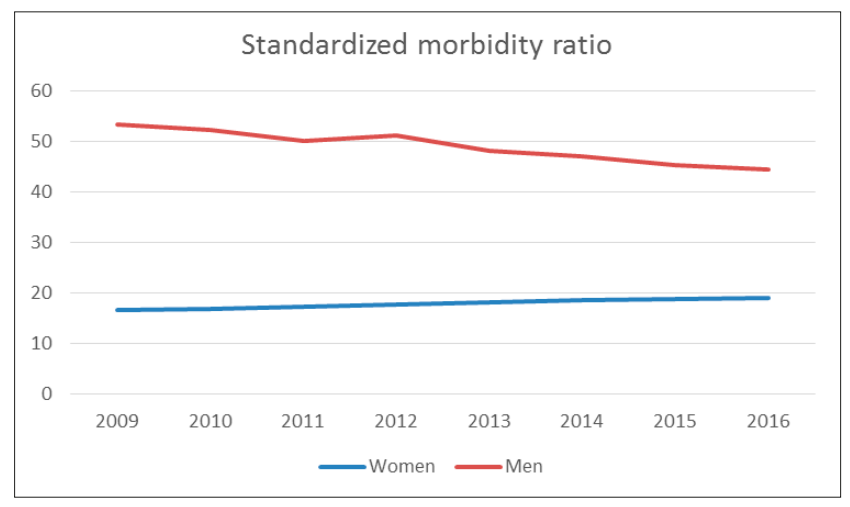

Figure 4. Standardized morbidity ratio for lung cancer [7]

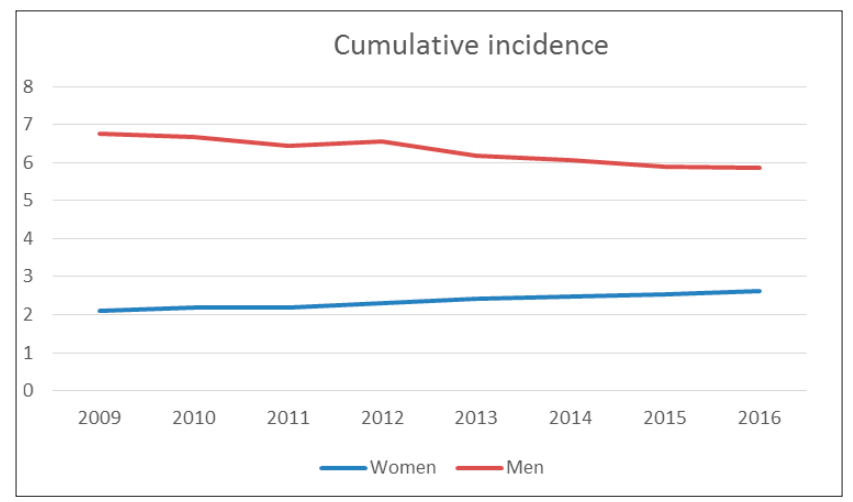

Figure 5. Cumulative incidence for lung cancer [7]

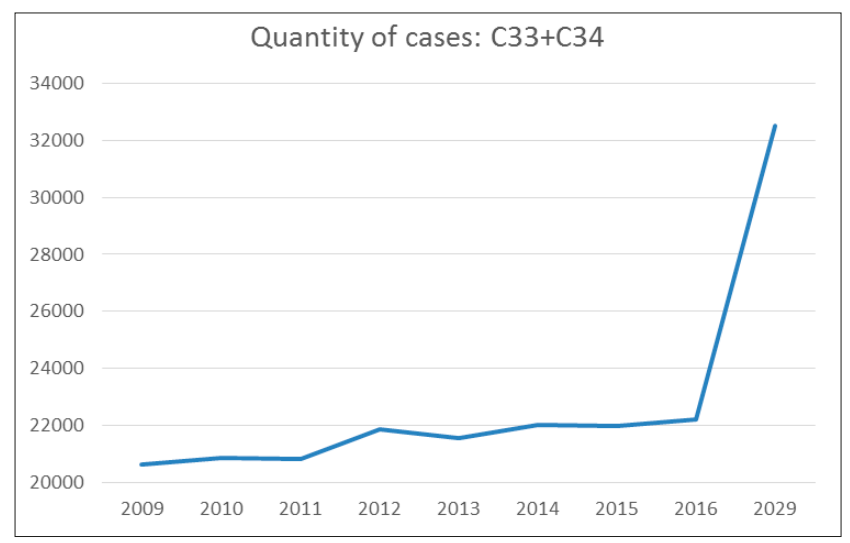

Figure 6. Quantity of cases $C 33+C 34[7,26]$

data presented in the Maps of Health Needs. Based on the National Cancer Registry, was taken into consideration. It was noticed that the Standardized morbidity ratio and the cumulative incidence increased for women, but for men it is decreasing. However, the risk of lung cancer is still about 3 times higher in men than in women.

Table 2. Calculated amount of 'passively' smoked cigarettes

\begin{tabular}{lccccccccc}
\hline & 2009 & 2010 & 2011 & 2012 & 2013 & 2014 & 2015 & 2016 & 2017 \\
\hline $\begin{array}{l}\text { Calculated amount } \\
\text { of passively } \\
\text { smoked cigarettes }\end{array}$ & 10,6 & 11,9 & 11,2 & 10 & 9,6 & 9,5 & 9,1 & 8,7 & 8,8 \\
\hline$+/-$ & 2,5 & 2,9 & 2,7 & 2,3 & 2,2 & 2,2 & 2,1 & 2 & 2 \\
\hline
\end{tabular}

In the calculations for the current study, the average concentrations of PM2.5 and NO2 across Poland were used. 
Unfortunately, the Chief Inspectorate for Environmental Protection does not carry out Black Carbon measurements. But based on the presented method, it was noted that the amount of passively smoked cigarettes has slightly reduced, although at present it is about half a pack a day. The current study on passive smoking discusses the level of pollution which corresponds to environmental tobacco smoke.

The method used for the calculations in the current was based on the relative risk describing the relationship between tobacco smoke exposure, and three key air pollutants: particles with an aerodynamic diameter smaller than $2.5 \mathrm{~mm}$ (PM2.5), nitrogen dioxide (NO2) and black carbon (BC), and four health factors (low birth weight, decreased lung function in children, cardiovascular mortality and lung malignant neoplasms) [22]. Due to the very extensive calculation formula proposed by Zee, Fischer ans Hok to calculate the amount of passively smoked cigarettes, it is not possible to fully include them in the presented study. The exact formula in the form of a spreadsheet is available as an attachment to the publication, Air pollution in perspective: Health risks of air pollution expressed in equivalent numbers of passively smoked cigarettes [22].

The limitation of the above study is a large number of factors affecting the incidence of lung cancer. Based on the above data, it is not possible to indicate exactly the extent of the increase in the incidence of lung cancer was caused by air pollution. In the current study this is represented by the amount of passively smoked cigarettes, among other factors.

One of the difficulties in presenting this material was the delay in publication of statistical data by the National Cancer Registry, which took almost three years. In addition, in the case of a formula to calculate the amount of passively smoked cigarettes proposed by Saskia C. van der Zee, Paul H. Fischer, Gerard Hoek, also included the concentration of Black Carbon, a measurement not carried out by the Main Inspectorate of Environmental Protection in Poland. Instead, Elemental Carbon is measured in five survey stations throughout the country; therefore, it was not is not included as a part of original formula. The effect of this may be the underestimation of the amount of passively smoked cigarettes. However, despite the absence of this one component, authors of the formula have permitted its use for estimated calculations.

\section{DISCUSSION}

In recent years, air pollution has slightly decreased or has remained at a similar level. For the purposes of the current study, the results have been averaged, which allows the drawing of conclusions about the national area. Unfortunately, it makes impossible any noting of particular differences between individual parts of the country. This requires a broader analysis as the administrative countrywide units are more or less agricultural or industrial. Moreover, the direction of moving air masses could also have an affect on the concentration of air pollutants in particular parts of the country.

The obtained results were compared with air quality standards published by the WHO, EU and Poland. As the standards proposed by the EU and Poland are more liberal, it could be supposed that this is dictated by economic objectives. Moreover, it is allowed to exceed the standards of NO2 concentration 35 days per year. WHO standards are more stringent, focusing on the impact of air pollution on health. Furthermore, stating that any overrun has a negative impact on health in general and, on the risk lung cancer in particular. The average measurements of $\mathrm{NO} 2$ concentration remained within the standard range in relation to all guidelines. In the case of PM10, the WHO norm was overrun, but in the EU and in Poland they were not; however, in the case of PM2.5, all standards were exceeded. WHO guidelines were exceeded by almost three times.

Despite a similar level of air quality (based on PM2.5, PM10 and $\mathrm{NO} 2$ concentration), or even a minor improvement, it can be seen that simultaneously there was a systematic increase in the incidence lung cancer. Several explanations may be assumed for this situation. First, that the contributing factor was the constant exceeding of standards in Poland, causing chronic inflammation [10]. Second, may be the intensive migration which may influences the quality of breathing air. Another explanation could be differences in air pollutants [29]. It can be supposed that the amount of air pollutants in Poland could result from the production of electricity generated mainly by coal-fired power stations. Many households obtain their energy from coal, and could be one of the reasons for the high concentration of PM2.5 [35]. However, according to the presented study, the concentration of pollutants is the most important, rather than their origin [36].

Every year, the problem of air pollution in Poland is reflected in media reports in the winter, when residents are beginning to notice deterioration in air purity. The appearance of an unpleasant odour, a stifling cough, especially in areas where there is no municipal heating system. Both awareness about the threat posed by poor air quality and the general environment begins to increase.

Based on the calculations [21], if it is assumed that the same quality of air is maintained throughout life, at the age of 60 (95\% of lung cancer incidences in Poland occurred in older peopled [7]), every inhabitant has 30 pack-years of smoking, which significantly increases the risk of cancer [30, 31].

According to the Health Maps of Needs for Oncology, a further increase in the incidence of lung cancer is expected. Unfortunately, this does not mean that health programmes have been designed to improve the situation. So far, only pilot studies on early detection of lung cancer have been conducted. Due to the growing problem of lung cancer, this year it was decided to launch a nationwide programme $f$ the early detection of lung cancer which, hopefully will reduce the mortality rate of lung cancer.

The current study has discussed one of the aspects that may affect lung cancer - air pollution (PM2.5, PM10 and NO2). However, it should not be forgotten that diseases, especially cancer, are caused not only by a single factor, but that etiology is multifactorial. It is worth paying attention to the number of global changes that have occurred and which impacted on non-communicable diseases: climate changes, urbanization, food, nutrition, and agriculture, persistent chemicals in the environment, and biodiversity loss. The impact of such a number of factors requires further comprehensive analysis $[37,38]$.

Observance of air quality standards in Western Europe has definitely improved. In Poland in 2016, as much as 58.7\% of the urban population were exposed to concentrations of PM10 above EU standards; for PM2.5 it was.5\%, compared 
to France, PM10 - 0.2\%; and Germany, PM2,5 - 0\%, and in the country nearest to us $-0.1 \%$ and $0 \%$ [39]. This may suggest that the authorities responsible for health and environmental care in Western countries appreciate the importance of the problem, and care more for the health of their citizens.

Due to numerous factors, in future studies will be worthwhile expanding the analysis by comparing them between countries in the context of the increasing incidence of lung cancer.

\section{CONCLUSIONS}

- Based on the above calculations, it can be assume that every inhabitant of Poland passively smokes almost half a pack of cigarettes per year/lifetime.

- After 60 years of age, every inhabitant of Poland has 30 package-years of smoking, which is the borderline in the discussion on increased risk of lung cancer

- PM2.5 and PM10 concentration standards are exceeded, not only according to the guidelines of the WHO, but also according to Polish law

\section{Conflict of interst}

The authors declare that there is no conflict of interest regarding the publication of this article.

\section{REFERENCES}

1. Polish Energy Market Agency, 2017

2. Jeričević A, Gašparac G, Mikulec MM, Kumar P, Prtenjak MT. Identification of diverse air pollution sources in a complex urban area of Croatia. J Environ Manage. 2019 Aug 1; 243: 67-77. doi: 10.1016/j. jenvman.2019.04.024. Epub 2019 May 9. PubMed PMID: 31078930.

3. World Bank and Institute for Health Metrics and Evaluation. 2016. The Cost of Air Pollution: Strengthening the Economic Case for Action. Washington, DC: World Bank. License: Creative Commons Attribution CC BY 3.0 IGO

4. Orru H, Maasikmets M, Lai T, et al. Health impacts of particulate matter in five major Estonian towns: main sources of exposure and local differences. Air Quality, Atmosphere \& Health 2011; 4: 247-58.

5. Franklin M, Koutrakis P, Schwartz P. The role of particle composition on the association between PM2.5 and mortality. Epidemiology. 2008 Sep; 19(5): 680-9.

6. World cancer report / edited by Bernard W. Stewart and Christopher P. Wild, 2014 ISBN 978-92-832-0443-5

7. Wojciechowska Urszula, Didkowska Joanna. Morbidity and mortality from malignant tumors in Poland. National Cancer Registry,- The Maria Skłodowska-Curie Institute - Oncology Center. Available at http://onkologia.org.pl/raporty/ access from 01/03/2019

8. Guo Y, Zeng H, Zheng R, Li S, Barnett AG, Zhang S, Zou X, Huxley R, Chen W, Williams G. The association between lung cancer incidence and ambient air pollution in China: A spatiotemporal analysis. Environ Res. 2016 Jan; 144(Pt A): 60-65. doi: 10.1016/j.envres.2015.11.004. Epub 2015 Nov 9. PubMed PMID:26562043.

9. Cui P, Huang Y, Han J, Song F, Chen K. Ambient particulate matter and lung cancer incidence and mortality: a meta-analysis of prospective studies. Eur J Public Health. 2015 Apr; 25(2): 324-9. doi: 10.1093/ eurpub/cku145. Epub 2014 Sep 8.PubMed PMID: 25201901.

10. Korniluk A, Koper O, Kemona H, Dymicka-Piekarska V. From inflammation to cancer. Ir J Med Sci. 2017 Feb;186(1):57-62. doi: 10.1007/s11845-016-1464-0. Epub 2016 May 7. Review. PubMed PMID: 27156054; PubMed Central PMCID: PMC5323483.

11. Jin Y, Wu W, Zhang W, Zhao Y, Wu Y, Ge G, Ba Y, Guo Q, Gao T, Chi $\mathrm{X}$, Hao H, Wang J, Feng F. Involvement of EGF receptor signaling and NLRP12 inflammasome in fine particulate matter-induced lung inflammation in mice. Environ Toxicol. 2017 Apr; 32(4): 1121-1134. doi: 10.1002/tox.22308. Epub 2016 Jul 5. PubMed PMID: 27377055.
12. Zhao H, Li W, Gao Y, Li J, Wang H. Exposure to particular matter increases susceptibility to respiratory Staphylococcus aureus infection in rats via reducing pulmonary natural killer cells. Toxicology. 2014 Nov 5;325:180-8. doi: 10.1016/j.tox.2014.09.006. Epub 2014 Sep 16. PubMed PMID: 25220797.

13. Cachon BF, Firmin S, Verdin A, Ayi-Fanou L, Billet S, Cazier F, Martin PJ, Aissi F, Courcot D, Sanni A, Shirali P. Proinflammatory effects and oxidative stress within human bronchial epithelial cells exposed to atmospheric particulate matter $(\operatorname{PM}(2.5)$ and $\operatorname{PM}(>2.5))$ collected from Cotonou, Benin. Environ Pollut. 2014 Feb;185:340-51. doi: 10.1016/j. envpol.2013.10.026. Epub 2013 Dec 10. PubMed PMID: 24333687.

14. Tecer LH, Alagha O, Karaca F, Tuncel G, Eldes N. Particulate matter (PM(2.5), PM(10-2.5), and PM(10)) and children's hospital admissions for asthma and respiratory diseases: a bidirectional casecrossover study. J Toxicol Environ Health A. 2008;71(8):512-20. doi: 10.1080/15287390801907459. PubMed PMID: 18338286.

15. Ji X, Han M, Yun Y, Li G, Sang N. Acute nitrogen dioxide (NO2) exposure enhances airway inflammation via modulating Th1/Th2 differentiation and activating JAK-STAT pathway. Chemosphere. 2015 Feb;120:722-8. doi: 10.1016/j.chemosphere.2014.10.039. Epub 2014 Nov 11. PubMed PMID: 25462318.

16. Al-Ahmadi K, Al-Zahrani A. $\mathrm{NO}(2)$ and cancer incidence in Saudi Arabia. Int J Environ Res Public Health. 2013 Nov 4;10(11):5844-62. doi: 10.3390/ijerph10115844. PubMed PMID: 24192792; PubMed Central PMCID: PMC3863874.

17. Marino E, Caruso M, Campagna D, Polosa R. Impact of air quality on lung health: myth or reality? Ther Adv Chronic Dis. 2015 Sep;6(5):28698. doi: 10.1177/2040622315587256. Review. PubMed PMID: 26336597; PubMed Central PMCID:PMC4549691.

18. Hamra GB, Laden F, Cohen AJ, Raaschou-Nielsen O, Brauer M, Loomis D. Lung Cancer and Exposure to Nitrogen Dioxide and Traffic: A Systematic Review and Meta-Analysis. Environ Health Perspect. 2015 Nov;123(11):1107-12. doi: 10.1289/ehp.1408882. Epub 2015 Apr 14. Review. PubMed PMID: 25870974; PubMed Central PMCID: PMC4629738.

19. Raaschou-Nielsen O, Andersen ZJ, Beelen R, Samoli E, Stafoggia M, Weinmayr G, Hoffmann B, Fischer P, Nieuwenhuijsen MJ, Brunekreef B, Xun WW, Katsouyanni K,Dimakopoulou K, Sommar J, Forsberg B, Modig L, Oudin A, Oftedal B, Schwarze PE, Nafstad P, De Faire U, Pedersen NL, Ostenson CG, Fratiglioni L, Penell J, Korek M, Pershagen G, Eriksen KT, Sørensen M, Tjønneland A, Ellermann T, Eeftens M, Peeters PH, Meliefste K, Wang M, Bueno-de-Mesquita B, Key TJ, de Hoogh K, Concin H, Nagel G, Vilier A, Grioni S, Krogh V, Tsai MY, Ricceri F, Sacerdote C, Galassi C, Migliore E, Ranzi A, Cesaroni G, Badaloni C, Forastiere F, Tamayo I, Amiano P,Dorronsoro M, Trichopoulou A, Bamia C, Vineis P, Hoek G. Air pollution and lung cancer incidence in 17 European cohorts: prospective analyses from the European Study of Cohorts for Air Pollution Effects (ESCAPE). Lancet Oncol. 2013 Aug;14(9):813-22. doi: 10.1016/S1470-2045(13)70279-1. Epub 2013 Jul 10. PubMed PMID: 23849838.

20. Couraud S, Zalcman G, Milleron B, Morin F, Souquet PJ. Lung cancer in never smokers--a review. Eur J Cancer. 2012 Jun;48(9):1299-311. doi: 10.1016/j.ejca.2012.03.007. Epub 2012 Mar 28. Review. PubMed PMID: 22464348.

21. van der Zee SC, Fischer PH, Hoek G. Air pollution in perspective: Health risks of air pollution expressed in equivalent numbers of passively smoked cigarettes. Environ Res. 2016 Jul;148:475-483. doi: 10.1016/j. envres.2016.04.001. Epub 2016 Apr 30. PubMed PMID: 27136673.

22. WHO Air quality guidelines for particulate matter, ozone, nitrogen dioxide and sulfur dioxide. World Health Organization 2006

23. Directive 2008/50/EC of the European Parliament and of the Council of 21 May 2008 on ambient air quality and cleaner air for Europe

24. REGULATION OF THE MINISTER OF THE ENVIRONMENT of August 24, 2012 on the levels of certain substances in the air

25. Database Main Inspectorate of Environmental Protection http:// powietrze.gios.gov.pl/pjp/archives

26. Maps of health needs - Database of System and Implementation Analyzes in the field of oncology prepared by the Ministry of Health of Poland

27. Piotr Wojtyś, Andrzej Antczak, Dariusz Godlewski, Predictions of cancer mortality, in Poland in 2020. Cent Eur J Med. 2014; 9(5): 667-675; DOI: $10.2478 / \mathrm{s} 11536-013-0307-\mathrm{x}$

28. Czaderny k. Determinants of Propensity for Cigarette Smoking. Results of Structural Equation Modelling. Studia Demograficzne 2017; 1(171): $49-69,67-68$

29. Wang T, Xia Z, Wu M, Zhang Q, Sun S, Yin J, Zhou Y, Yang H. Pollution characteristics, sources and lung cancer risk of atmospheric 
polycyclic aromatic hydrocarbons in a new urban district of Nanjing, China. J Environ Sci (China). 2017 May; 55:118-128. doi: 10.1016/j. jes.2016.06.025. Epub 2016 Aug 15. PubMed PMID: 28477805.

30. Pinsky PF, Zhu CS, Kramer BS. Lung cancer risk by years since quitting in 30+ pack year smokers. J Med Screen. 2015 Sep;22(3):151-7. doi: 10.1177/0969141315579119. Epub 2015 Apr 29. PubMed PMID: 25926339.

31. Pinsky PF, Kramer BS. Lung Cancer Risk and Demographic Characteristics of Current 20-29 Pack-year Smokers: Implications for Screening. J Natl Cancer Inst. 2015 Oct 19;107(11). pii: djv226. doi: 10.1093/inci/djv226. Print 2015 Nov. PubMed PMID: 26483244; PubMed Central PMCID: PMC4849359.

32. Wilson, JM, Junger, G. Principles and Practice of Screening for Disease. Genewa; WHO, 1968

33. Goffin JR, Flanagan WM, Miller AB, Fitzgerald NR, Memon S, Wolfson MC, Evans WK. Cost-effectiveness of Lung Cancer Screening in Canada. JAMA Oncol. 2015 Sep; 1(6): 807-13. doi: 10.1001/jamaoncol.2015.2472. PubMed PMID: 26226181.

34. Pope CA 3rd, Cropper M, Coggins J, Cohen A. Health benefits of air pollution abatement policy: Role of the shape of the concentrationresponse function. J Air Waste Manag Assoc. 2015 May; 65(5):516-22. doi: 10.1080/10962247.2014.993004.PubMed PMID: 25947311.

35. Li Q, Jiang J, Wang S, Rumchev K, Mead-Hunter R, Morawska L, Hao J. Impacts of household coal and biomass combustion on indoor and ambient air quality in China: Current status and implication. Sci Total
Environ. 2017 Jan 15;576:347-361. doi: 10.1016/j.scitotenv.2016.10.080. Epub 2016 Oct 25. PubMed PMID: 27792953.

36. Cohen AJ, Brauer M, Burnett R, Anderson HR, Frostad J, Estep K, Balakrishnan K, Brunekreef B, Dandona L, Dandona R, Feigin V, Freedman G, Hubbell B, Jobling A, Kan H, Knibbs L, Liu Y, Martin R, Morawska L, Pope CA 3rd, Shin H, Straif K, Shaddick G, Thomas M, van Dingenen R, van Donkelaar A, Vos T, Murray CJL, Forouzanfar MH. Estimates and 25-year trends of the global burden of disease attributable to ambient air pollution: an analysis of data from the Global Burden of Diseases Study 2015. Lancet. 2017 May 13;389(10082):1907-1918. doi: 10.1016/S0140-6736(17)30505-6. Epub 2017 Apr 10. Erratum in: Lancet. 2018 Apr 21;391(10130):1576. Lancet. 2017 Jun 17;389(10087):e15. PubMed PMID: 28408086; PubMed Central PMCID: PMC5439030.

37. Eckel SP, Cockburn M, Shu YH, Deng H, Lurmann FW, Liu L, Gilliland FD. Air pollution affects lung cancer survival. Thorax. 2016 Oct; 71(10):891-8. doi: 10.1136/thoraxjnl-2015-207927. Epub 2016 Aug 4. PubMed PMID: 27491839; PubMed Central PMCID: PMC5400105.

38. Frumkin H, Haines A. Global Environmental Change and Noncommunicable Disease Risks. Annu Rev Public Health. 2019 Jan 11. doi:10.1146/annurev-publhealth-040218-043706. [Epub ahead of print] PubMed PMID: 30633714.

39. European Environment Agency - https://www.eea.europa.eu access from 28.01.2019

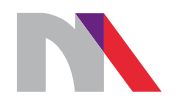

Ministry of Science and Higher Education

Republic of Poland

Generation of the DOI (Digital Object Identifier) - task financed under the agreement No. 618/P-DUN/2019 by the Minister of Science and Higher Education 